\title{
PEMBUATAN VIRGIN COCONUT OIL DENGAN BANTUAN ENZIM BROMELAIN SEBAGAI ALTERNATIF PRAKTIKUM DI SMAN KAMPAR Alwan Hendri, Fitri Refelita.
}

\author{
Fakultas Tarbiyah dan Keguruan, UIN Sultan Syarif Kasim Riau (Alwan Hendri) \\ E-mail:alwanhendri5@gmail.com \\ Program Studi Pendidikan Kimia, Fakultas Tarbiyah dan Keguruan, Universitas Islam Negeri \\ Sultan Syarif Kasim Riau, Jalan Subrantas Km.15, Pekanbaru, 28293, Telp: 0761-562223
}

\begin{abstract}
Making coconut oil was usually done with heating coconut milk for hours until the protein in coconut milk broke and the oil can go out from coconut milk emulsion. The aim of this study was to determine the effect of pineapple juice addition against the amount of produced oil, to determine the quality of VCO enzymatic were density, water content, organoleptic (color, smell and flavor), teacher appraisal on work procedure and product of study result. The variation of pineapple juice shown that more pineapple juice addition then more produced VCO. The mount of produced oil for sample A $80 \mathrm{~mL}$, sample $B 83 \mathrm{~mL}$ and sample $C 85 \mathrm{~mL}$. The quality of three samples were for density which sample $A 0.916$, sample $B$ 0.938, sample $C 0.95$. And for water content which sample A0.5, sample B 0.83 dan sample C 1.16. Between three sample, only sample A was accordance with SNI (Indonesia National Standard) No. 7381:2008 which for density was (0.91-0.92) and water content (0.1-0.5\%). The teacher appraisal questionnaire about study result and appropriateness of VCO manufacture enzymatic gave cumulative value was $83.20 \%$ and it was in very good category.

Keyword: VCO (Virgin Coconut Oil), Kelapa (Coconut nucifera L), Enzim Bromelain, Nanas (Ananas comosus L)
\end{abstract}

\section{PENDAHULUAN}

Tanaman kelapa sangat bermanfaat bagi kehidupan manusia karena hampir semua bagian kelapa dapat dimanfaatkan. Salah satunya adalah daging buah kelapa yang dapat di pakai sebagai bahan baku penghasil santan. Santan diperoleh dengan pemerasan terhadap daging buah kelapa.

Santan merupakan bahan makanan yang dipergunakan untuk mengolah berbagai masakan seperti daging, ikan, ayam, dan untuk pembuatan berbagai kue-kue, es krim, gulagula. Santan ini juga dapat menghasilkan produk olahan yang populer belakangan ini ramai diperbincangkan karena kualitasnya yaitu Virgin Coconut Oil (VCO)[1].

VCO adalah salah satu bahan pangan sumber lemak yang sekarang ini banyak diminati karena khasiatnya bagi kesehatan.Dibandingkan dengan minyak nabati lainnya, VCO memiliki banyak keunggulan yaitu kandungan asam laurat yang tinggi yang berfungsi sebagai antivirus, antiprotozoa dan anti bakteri. VCO sangat baik untuk kesehatan seperti meningkatkan daya tahan tubuh terhadap penyakit dan mempercepat penyembuhan penyakit serta tidak mendorong terjadinya kegemukan atau obesitas. 
VCO juga mengandung antioksidan yang mengaktifkan hormon-hormon anti penuaan dan penuaan dini. Oleh karena itu harganya cukup mahal[2]. Dalam pembuatan VCO dapat dilakukan dengan berbagai cara salah satunya dengan cara enzimatis.

Pembuatan VCO secara enzimatis merupakan pembuatan VCO dari santan kelapa dengan bantuan enzim. VCO yang dihasilkan dari proses enzimatis ini memiliki keunggulan antara lain, kandungan lemak pada VCO tidak banyak berubah sehingga khasiatnya tetap terjaga, tidak mudah tengik karena komposisi asam lemaknya tidak banyak berubah dan rendamen yang dihasilkan tinggi[3]. Salah satu enzim yang dapat digunakan dalam proses pembuatan VCO yaitu enzim bromelain yang berasal dari nanas.

Buah nanas adalah tumbuhan herbal yang mudah ditemui, harganya relatif murah[4]. Dalam proses pembuatan VCO secara enzimatis salah satu yang sangat mempengaruhi yaitu jumlah enzim yang digunakan dalam proses pembuatan VCO itu sendiri. Untuk menghasilkan minyak VCO dengan kualitas yang bagus dapat kita lihat dari segi warna, rasa, aroma, densitas dan kadar air yang dihasilkan oleh minyak VCO.

Berdasarkan uraian tersebut, maka peneliti tertarik untuk melakukan penelitian PEMBUATAN VIRGIN COCONUT OIL DENGAN BANTUAN ENZIM

BROMELAIN SEBAGAI ALTERNATIF PRAKTIKUM DI SMAN KAMPAR

\section{METODE}

Penelitian dilaksanakan pada bulan Maret sampai dengan April 2016.Penelitian dilaksanakan di Laboratorium Pendidikan Kimia UIN SUSKA Riau, SMA Negeri 1 Kampar, dan SMA Negeri 2 Kampar. Subjek dalam penelitian ini adalah 5 orang guru kimia yang di ambil dari 2 sekolah yaitu 3 orang guru kimia SMA Negeri 1 Kampar dan 2 orang guru SMA Negeri 2 Kampar. Objek dari penelitian ini adalah Pembuatan VCO (Virgin Coconut Oil) Dari Kelapa (Coconut Nucifera L) Dengan Bantuan Enzim Bromelain Dari Buah Nanas (Ananas Comosus L) Sebagai Alternatif Praktikum Kimia Di Sekolah Menengah Atas Negeri Kampar. Sampel yang digunakan dalam penelitian ini adalah buah kelapa. 6 Buah Kelapa (Cocos nucifera L) warna kehitaman dan yang sudah tua dan 1 buah nanas yang hampir masak, Ada tiga prosedur yang dilakukan dalam penelitian ini yaitu:

\section{a. Pembuatan Krim Santan}

Buah kelapa yang sudah dikupas diambil daging buahnya kemudian diparut dengan mesin pemarut dan ditambahkan air dengan perbandingan 1:1, kemudian diremas-remas dan diperas. Selanjutnya lakukan penambahan air untuk kedua kalinya dengan perbandingan 1:1 pemerasan diulangi lagi dengan cara yang sama. Santan yang telah diperoleh dimasukkan kedalam toples dan tutup rapat selama 2 jam hingga terbentuk dua lapisan. Lapisan atas dinamakan dengan krim, sedangkan lapisan 
bawah dinamakan dengan skim (air santan). Kemudian diambil krim santan untuk pembuatan $\mathrm{VCO}[5]$.

\section{b. Pembuatan Sari Buah Nanas}

Kupas kulit nanas dengan menggunakan pisau dapur kemudian nanas dipotong bentuk dadu nanas dan dihaluskan menggunakan blender kemudian ditimbang dengan timbangan analitik masing masing $100 \mathrm{~g}, 200 \mathrm{~g}$ dan $300 \mathrm{~g}$.

\section{c. Pembuatan VCO Dengan Metode Enzimatis}

Diambil krim santan tadi sebanyak $900 \mathrm{ml}$ kemudian dimasukkan kedalam beaker gelas $1000 \mathrm{ml}$ dibagi $300 \mathrm{ml}$ setiap beaker gelas. Tambahkan sari buah nanas kedalam krim santan yang telah disediakan. Aduk hingga merata dan tutup dengan alumunium foil dan diberi label. Diamkan campuran tersebut selama $( \pm 22$ jam). Setelah terbentuk tiga lapisan, pisahkan minyak dengan sentrifugasi. Minyak VCO yang didapatkan dimasukkan kedalam gelas kimia dan dilihat jumlah minyak yang dihasilkan masing-masing sampel.[6].

\section{d. Penilaian}

Peneliti menampilkan video pelaksanaan penelitian dan membawa minyak VCO hasil produk dari peneliti kepada guru-guru mata pelajaran kimia dan meminta tanggapan mengenai warna, aroma dan rasa, kepraktisan cara kerja dan kesesuaian dengan materi lipid melalui angket yang diberikan. Demonstrasi dilakukan kepada 5 orang guru kimia di 2 SMA Kecamatan Kampar, yaitu tiga orang guru kimia SMA Negeri 1 Kampar dan dua orang guru kimia SMA Negeri 2 Kampar.

Secara kuantitatif untuk mengakumulasi semua jawaban responden dari setiap Pertanyaan ditentukan dari persentase hasil penelitian, yaitu dengan menggunakan rumus:

$$
\mathrm{P}=\mathrm{F} / \mathrm{N} \times 100 \%[7]
$$

Dengan keterangan:

$\mathrm{P}=$ Persentase

$\mathrm{N}=$ Total Jumlah

$\mathrm{F}=$ Frekuensi Responden

\section{HASIL DAN PEMBAHASAN}

a. Hasil minyak VCO

Minyak yang dihasilkan dari penelitian ini adalah minyak VCO dengan perbandingan jumlah yaitu untuk sampel A (100 g sari buah nanas: $300 \mathrm{~mL}$ santan murni) didapatkan $80 \mathrm{~mL}$, untuk sampel B (200 g sari buah nanas : $300 \mathrm{~mL}$ santan murni) didapatkan $83 \mathrm{~mL}$ dan untuk sampel C (300 g sari buah nanas : $300 \mathrm{~mL}$ santan murni) didapatkan $85 \mathrm{~mL}$. Dari data diatas dapat kita ambil kesimpulan bahwa semakin banyak sari buah nanas yang kita tambahkan pada krim santan maka semakin banyak pula minyak VCO yang diperoleh[8].

Hal ini karena semakin banyak enzim bromelain yang terdapat pada campuran maka akan semakin banyak pula enzim tersebut memecahkan atau merusak emulsi sehingga semakin banyak minyak VCO yang berhasil keluar dari emulsi minyak dalam air / . Semakin banyak enzim bromelain yang ditambahkan maka akan semakin cepat proses 
hidrolisis protein oleh enzim bromelain tersebut. Enzim ini akan merusak ikatan peptida protein sehingga protein dapat terdenaturasi menjadi komponen yang lebih sederhana yakni asam amino dan komponen lainnya. Sebaliknya semakin sedikit kita tambahkan sari buah nanas maka semakin sedikit pula enzim bromelain yang ada didalamnya. Sehingga jumlah protein yang dihidrolisispun juga sedikit dan semakin lama pulalah proses denaturasi protein sehingga minyak yang dihasilkan juga tidak banyak.

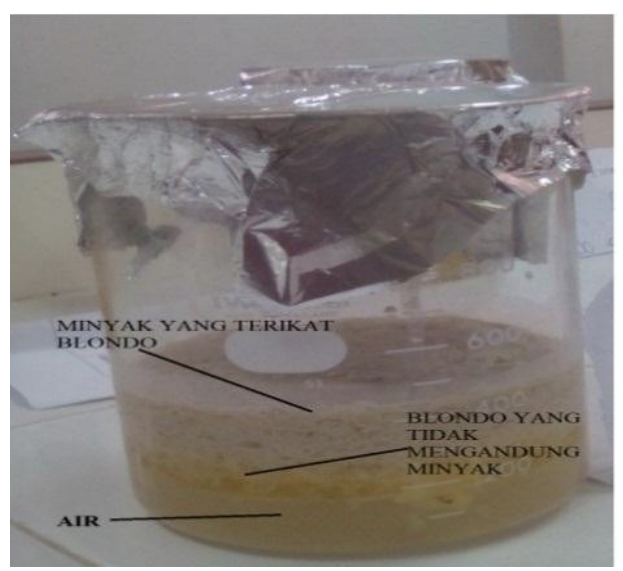

Gambar I.1 Komponen-komponen minyak

Ketika proses denaturasi protein oleh enzim bromelain berlangsung minyak yang telah bebas bisa keluar dari emulsi dan menuju ke bagian atas wadah yang digunakan. Hal ini merupakan pengaruh dari masa jenis minyak yang paling kecil diantara tiga komponen yang ada dalam wadah (air, blondo dan minyak VCO). Hal ini juga akan mempermudah kinerja yang mana kita hanya perlu mengambil minyak-minyak dan blondo saja untuk dilakukan sentrifius[9].

Fungsi dari sentrifius ini adalah untuk memisahkan minyak VCO yang masih terikat didalam blondo.Minyak VCO yang ada didalam blondo ini pada dasar nya sudah bebas namun masih terikat sebagian oleh protein.Hal ini dikarenakan enzim bromelain yang ada sudah bereaksi hampir semunya kinerja dari enzim tersebut sudah tidak kuat lagi.Sehingga minyak VCO tersebut masih terdapat di dalam blondo, ketika dilakukan sentrifius maka minyak VCO yang berada paa blondo bisa keluar karena perputaran sentrifius yang sangat tinggi.

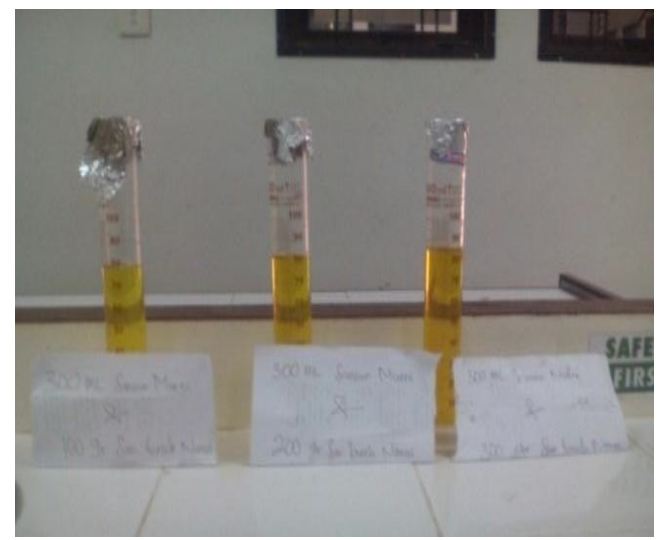

Gambar I.2 Hasil minyak VCO

Tabel I.1. Hasil perbandingan minyak VCO yang dihasilkan yaitu dengan perbandingan 300 $\underline{\mathrm{ml} / 100 \mathrm{~g} 300 \mathrm{ml} / 200 \mathrm{~g} 300 \mathrm{ml} / 300 \mathrm{~g} .}$

\begin{tabular}{cccc}
\hline Sampel & $\begin{array}{c}\text { Santan } \\
\text { Murni } \\
(\mathbf{m L})\end{array}$ & $\begin{array}{c}\text { Sari } \\
\text { buah } \\
\text { Nanas } \\
\text { (g) }\end{array}$ & $\begin{array}{c}\text { Minyak VCO } \\
\text { yang } \\
\text { dihasilkan } \\
\text { (mL) }\end{array}$ \\
\hline A & 300 & 100 & 80 \\
B & 300 & 200 & 83 \\
C & 300 & 300 & 85 \\
\hline
\end{tabular}




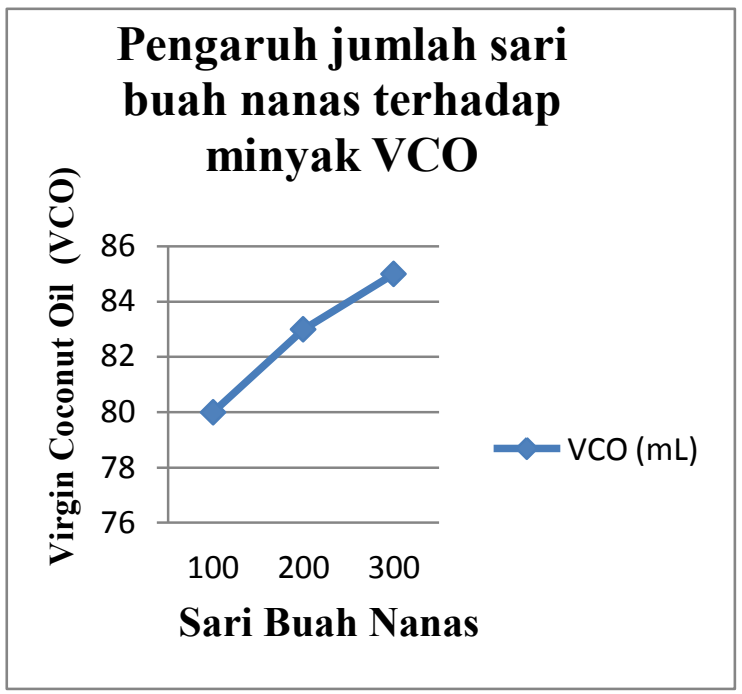

Grafik I.1 Pengaruh jumlah sari buah nanas terhadap minyak VCO

\section{A. Hasil kualitatif minyak VCO (Virgin Coconut Oil)}

1. Uji Organoleptik

Tabel I.2. Hasil uji organoleptik terhadap minyak VCO yang dihasilkan

\begin{tabular}{cccc}
\hline Sampel & Rasa & Aroma & Warna \\
& & & \\
\hline A & Normal & Normal & Normal \\
B & Normal & Normal & Normal
\end{tabular}

\begin{tabular}{llll} 
C Normal Normal Normal \\
\hline
\end{tabular}

Keterangan:

Rasa $\quad$ Normal $=$ Rasa kelapa khas, dan tidak tengik

Aroma $:$ Normal $=$ Bau kelapa khas

Warna : Normal $=$ Jernih tidak berwarna sampai kuning

2. Uji Densitas

Uji densitas merupakan pengujian terhadap masa jenis dari zat yang merupakan perbandingan antara massa dan voleme zat pada suhu tertentu dan dalam penelitian ini suhunya dalah $29 \mathrm{C}^{\circ}$ dan densitas yang diujikan yang pertama sampel A (100 g sari buah nanas: 300 $\mathrm{mL}$ santan murni) memiliki densitas 0.916, sampel B (200 g sari buah nanas : $300 \mathrm{~mL}$ santan murni) memiliki densitas 0.938 dan $\mathrm{C}$ (300 g sari buah nanas : $300 \mathrm{~mL}$ santan murni) memiliki densitas 0.95 .

Dari hasil pengukuran yang didapatkan dapat dilihat terjadi kenaikan densitas dari masing-masing sampel yang diujikan yang paling rendah yaitu sampel A kemudian naik ke sampel B dan naik lagi ke sampel C. Artinya semakin banyak ditambahkan sari buah nanas maka densitas juga akan semakin meningkat begitu pula sebaliknya semakin sedikit ditambahkan sari buah nanas akan menghasilkan densitas yang juga rendah. Standar SNI 7381:2008 menyatakan densitas untuk minyak VCO yaitu 0.91-0.92 dan diantara ketiga sampel hanya sampel A yan sesuai dengan kreteria sementara untuk B dan C tidak sesuai kreteria[10] 
Tabel I.3. Hasil perhitungan densitas $(\rho)$

\begin{tabular}{ccccc}
\hline $\begin{array}{c}\text { Sam } \\
\text { pel }\end{array}$ & $\begin{array}{c}\text { Volu } \\
\text { me } \\
\text { Pikno } \\
\text { Meter }\end{array}$ & $\begin{array}{c}\text { Berat } \\
\text { Pikno } \\
\text { meter } \\
\text { Kosong }\end{array}$ & $\begin{array}{c}\text { Berat } \\
\text { Pikno } \\
\text { meter } \\
\text { Berisi }\end{array}$ & $\begin{array}{c}\text { Hasil } \\
\text { Perhit } \\
\text { ungan }\end{array}$ \\
\hline A & $10 \mathrm{~mL}$ & 8.68 & 17.84 & 0.916 \\
\hline B & $10 \mathrm{~mL}$ & 8.68 & 18.06 & 0.938 \\
\hline C & $10 \mathrm{~mL}$ & 8.68 & 18.18 & 0.950 \\
\hline
\end{tabular}

1. Uji kadar air

Uji kadar air merupakan pengujian melihat kandungan air yang terdapat pada suatu sampel yaitu dengan cara pemanasan dengan oven. Disini kita gunakan oven dengan merk Thermo dengan pemanasan 100-105 $\mathrm{C}^{\circ}$ selama 2 jam dan kemudian dimasukkan kedalam desikator dan ditimbang dilakukan 3 kali pengulangan. Sampel yang pertama yaitu sampel A (100 g sari buah nanas : $300 \mathrm{~mL}$ santan murni) memiliki rata-rata kadar air $0.5 \%$, sampel $\mathrm{B}$ (200 g sari buah nanas : $300 \mathrm{~mL}$ santan murni) memiliki memiliki rata-rata kadar air $0.83 \%$ dan sampel C (300 g sari buah nanas : $300 \mathrm{ml}$ santan murni) memiliki memiliki rata-rata kadar air $1.16 \%$. Dari uraian diatas didapatkan hasil semakin meningkatnya kadar air minyak VCO dari A, B dan C. hal ini dikarenakan jumlah sari buah nanas yang ditambahkan pada samtan sangat mempengaruhi kadar air dari minyak VCO, secara kuantitatif mamang semakin banyak penambahan sari buah nanas semakin banyak pula minyak VCO yang dihasilkan namun secara kualitatif justru berbanding terbalik semakin sedikit ditambahkan maka akan didapatkan kadar air yang juga rendah. Menurut Standar SNI

7381:2008 menyatakan kadar air untuk minyak VCO yaitu $0.1-0.5 \%$ dan diantara ketiga sampel hanya sampel A yang sesuai dengan kreteria sementara untuk B dan $\mathrm{C}$ tidak sesuai kreteria[11].

Sampel A

Tabel I.4. Hasil perhitungan kadar air dari minyak VCO yang dihasilkan yaitu dengan perbandingan $100 \mathrm{~g}$ sari nanas $300 \mathrm{ml}$ krim santan

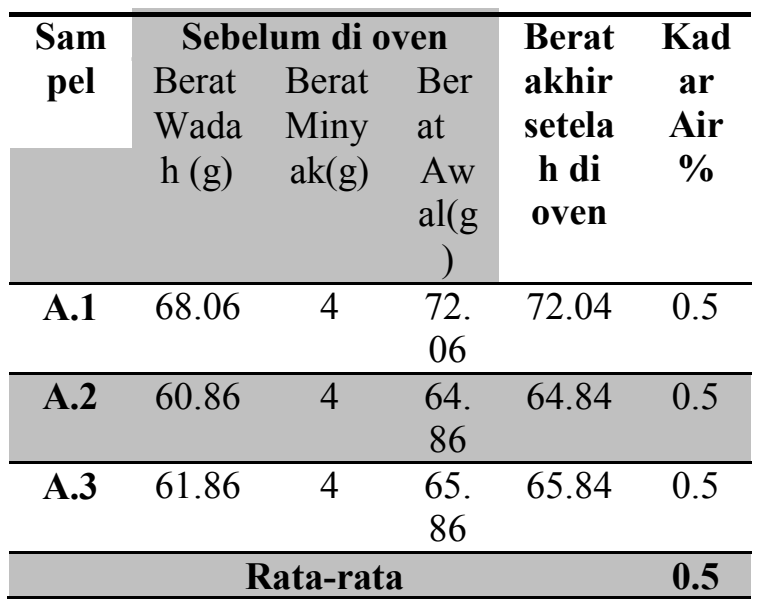

Sampel B

Tabel IV.5. Hasil perhitungan kadar air dari minyak VCO yang dihasilkan yaitu dengan perbandingan $100 \mathrm{~g}$ nanas $300 \mathrm{ml}$ krim santan

\begin{tabular}{|c|c|c|c|c|c|}
\hline \multirow{2}{*}{$\begin{array}{c}\text { Samp } \\
\text { el }\end{array}$} & \multicolumn{3}{|c|}{ Sebelum di oven } & \multirow[b]{2}{*}{$\begin{array}{c}\text { Berat } \\
\text { akhir } \\
\text { setela } \\
\text { h } \\
\text { diove } \\
\text { n }\end{array}$} & \multirow{2}{*}{$\begin{array}{c}\text { Kad } \\
\text { ar } \\
\text { Air } \\
\%\end{array}$} \\
\hline & $\begin{array}{l}\text { Berat } \\
\text { Wadah } \\
\text { (g) }\end{array}$ & $\begin{array}{l}\text { Berat } \\
\text { Miny } \\
\operatorname{ak}(g)\end{array}$ & $\begin{array}{c}\text { Berat } \\
\text { Awal } \\
\text { (g) }\end{array}$ & & \\
\hline B.1 & 62.14 & 4 & $\begin{array}{c}66.1 \\
4\end{array}$ & 66.12 & 0.5 \\
\hline B.2 & 60.06 & 4 & $\begin{array}{c}64.0 \\
6\end{array}$ & 64.02 & 1 \\
\hline $\mathbf{B . 3}$ & 61.76 & 4 & $\begin{array}{c}65.7 \\
6\end{array}$ & 65.72 & 1 \\
\hline & & ata-rata & & & 0.83 \\
\hline
\end{tabular}


Sampel C

Tabel IV.6. Hasil perhitungan kadar air dari minyak VCO yang dihasilkan yaitu dengan perbandingan $100 \mathrm{~g}$ sari nanas $300 \mathrm{ml} \mathrm{krim}$ santan

\begin{tabular}{|c|c|c|c|c|c|}
\hline \multirow{2}{*}{$\begin{array}{c}\text { Sam } \\
\text { pel }\end{array}$} & \multicolumn{3}{|c|}{ Sebelum di oven } & \multirow{2}{*}{$\begin{array}{c}\text { Berat } \\
\text { akhir } \\
\text { setela } \\
\text { h } \\
\text { dioven }\end{array}$} & \multirow{2}{*}{$\begin{array}{c}\text { Kad } \\
\text { ar } \\
\text { Air } \\
\%\end{array}$} \\
\hline & $\begin{array}{c}\text { Berat } \\
\text { Wadah } \\
\text { (g) }\end{array}$ & $\begin{array}{l}\text { Berat } \\
\text { Miny } \\
\text { ak }(g)\end{array}$ & $\begin{array}{c}\text { Berat } \\
\text { Awal } \\
\text { (g) }\end{array}$ & & \\
\hline C.1 & 61.16 & 4 & $\begin{array}{c}65.1 \\
6\end{array}$ & 65.12 & 1 \\
\hline C.2 & 59.30 & 4 & $\begin{array}{c}63.3 \\
0\end{array}$ & 63.28 & 1 \\
\hline C.3 & 61.24 & 4 & $\begin{array}{c}65.2 \\
4\end{array}$ & 65.18 & 1.5 \\
\hline & & Rata-rat & & & 1.16 \\
\hline
\end{tabular}

\section{B. Penilaian}

Setelah didapatkan hasil minyak VCO dan diuji organoleptik, densitas dan kadar airnya, maka dibuat video dalam bentuk movie maker dan kemudian video dan produk yang telah selesai tersebut dibawa kesekolah untuk di persentasikan di depan guru responden. Setelah menyaksikan video persentasi yang dilakukan oleh peneliti, guru berikan produk untuk uji organoleptik (warna, aroma, rasa) dan diberikan angket untuk memberikan pendapat tentang pembuatan VCO secara enzimatis.Berikut merupakan hasil jawaban guru responden tentang warna yang dihasilkan VCO secara enzimatis.

Berdasarkan rekapitulasi angket penilaian guru terhadap kelayakan pembuatan VCO dari kelapa (Coconut nucifera L) dari buah nanas
(Ananas comosus L) sebagai alternatif praktikum pada materi kimia diperoleh:

1. Alternatif jawaban sangat baik 7

2. Alternatif jawaban baik 15

3. Alternatif jawaban cukup baik 3

4. Alternatif jawaban kurang baik 0

5. Alternatif jawaban tidak baik 0

Berdasarkan rekapitulasi diatas, maka:

1. Alternatif jawaban sangat baik $7 \times 5=35$

2. Alternatif jawaban baik $15 \times 4=60$

3. Alternatif jawaban cukup baik $3 \times 3=9$

4. Alternatif jawaban kurang baik $0 \times 2=0$

5. Alternatif jawaban tidak baik

$$
0 \times 1=0
$$

$25 \quad 104$

Nilai kumulatif hasil penelitian sebagai sumber belajar adalah 40 , sedangkan nilai yang diharapkan adalah $25 \times 5=125$

$$
\begin{aligned}
& P=-x 100 \% \\
& P=-\times 100 \% \\
& P=83,20 \%
\end{aligned}
$$

Berdasarkan hasil setelah dipersentasekan lalu angka ditafsirkan dengan kalimat yang bersifat kualitatif, dimana hasil penilaian guru mengenai hasil penelitian sebagai alternatif praktikum masuk pada kategori sangat baik yang memasuki rentang $81 \%-100 \%[12]$. 


\section{SIMPULA}

N

Berdasarkan hasil penelitian dan pembahasan dalam penelitian ini dapat diambil kesimpulan Variasi jumlah gram sari buah nanas berpengaruh terhadap jumlah minyak yang dihasilkan dalam proses pembuatan VCO. Semakin banyak jumlah sari buah nanas yang digunakan, semakin banyak pula minyak VCO yang dihasilkan, dan berbanding lurus dengan penambahan 100, 200, 300 $\mathrm{g}$ sari buah nanas

yaitu $80 \mathrm{ml}, 83 \mathrm{ml}$, $85 \mathrm{ml}$.

Kualitas minyak VCO yang di hasilkan dari segi uji organoleptik semuanya normal baik berupa warna, rasa, aroma. Densitas dari minyak VCO ini hanya sampel A (100 g sari buah nanas : $300 \mathrm{ml} \mathrm{krim} \mathrm{santan)} \mathrm{yang} \mathrm{sesuai}$ kreteria sampel B (200 g sari buah nanas : $300 \mathrm{ml}$ krim santan) dan C (300 g sari buah nanas :

$300 \mathrm{ml}$ krim santan) tidak sesuai dengan kreteria dan kadar air juga sama hanya sampel A (100 g sari buah nanas : $300 \mathrm{ml}$ krim santan) yang sesuai kreteria sampel B (200 g sari buah nanas : $300 \mathrm{ml}$ krim santan) dan C (300 g sari buah nanas : $300 \mathrm{ml}$ krim santan) tidak sesuai dengan kreteria. Dari analisis jawaban angket didapatkan penilaian hasil penelitian sebesar $83,20 \%$ dan termasuk kategori sangat baik.

\section{DAFTAR PUSTAKA}

[1] Hariyadi. (2008). Budidaya Tanaman Kelapa (Coconut Nucifera L)(hal 1). Bogor: IPB.

[2] Andi. (2005). Virgin Coconut Oil (hal 23).Tangerang: Agromedia Pustaka.

[3] Fajrin. (2012). Penggunaan Enzim Bromelain Pada Pembuatan Minyak Kelapa Secara Enzimatis, vol 11(no.3), hal 70.

[4] Azwar. (2010). Tanaman Obat

Indonesia

2(hal 36). Palembang: Malemba Medika.[5]Winarti. (2007). Proses Pembuatan VCO Virgin Coconut Oil Secara Enzimatis(hal 44). Jakarta:
Penebar Swadaya.

[6] Syukur. (2004). Bioteknologi Virgin Coconut Oil Peningkatan Kesehatan Total Dan Penegntasan Kemiskinan Masyarakat Pedesaan, vol 4(no 5),hal 21.

[7] Sudijono. (2007). Pengantar Statistik Pendidikan(hal 62). Jakarta: Raja Grafindo Persada.

[8] Sari. (2010). Pembuatan VCO dengan Metode Enzimatis dan Konversinya menjadi Sabun Padat Transparan, vol 8 (no 3), hal 53.

[9] Rasyidi. (2006). Pembuatan Virgin

Coconut Oil dengan Centrifugasi, vol 13 (no 5), hal 62.

[10] Ramlan. (2010). Pembuatan Virgin

Coconat Oil (VCO) Melalui

Kombinasi

Teknik Fermentasi dan

Enzimatis

Menggunakan Ekstrak Nenas, vol 8 (no 2), hal 33.

[11] Cristanti. (2009). Pembuatan Minyak Kelapa Murni (Virgin Coconut Oil)menggunakan fermentasi ragi tape, vol 6(no 4), hal 42.

(12) Riduwan, (2011), Skala Pengukuran Variabel-Variabel penelitian (hal 37), 